The implications of a rise in collagen in connective tissues distinct from those bearing the actual lesion are of great interest. It appears that in the carly stages of response to injury, the body proteins may be classified into three groups: $(a)$ those which do not maintain their normal tissue concentration and are depleted; $(b)$ those which maintain their normal concentration; and (c) those which exhibit an elevated concentration. In category $(a)$ will fall muscle proteins ${ }^{8}$, in $(b)$ proteins from liver ${ }^{8}$, and in (c) we can at the present moment place only collagen. The humoral or other factors controlling this multiple response must be quite complex.

I thank Mr. J. C. Lai for his technical assistance, and Dr. Y. E. Hsia for helpful discussions.

J. K. Candisish

Department of Biochemistry,

Faculty of Medicine,

University of Malaya,

Kuala Limpur.

2 Peacock, E. E., J. Surg. Rex,, 3, 250 (1963).

' Houck, J. C., Jacob, R. A., and DeAngelo, L., Surgery, 51, 386 (1962).

${ }^{3}$ Smith, Q. T., and Wogensen, J. K., J. Invest. Dermatol., 40, 213 (1963).

-Adamsons, R. J., Musco, F., and Enquist, 1. F., Surg. Gynecol. Obstet., 2, 323 (1964)

${ }^{5}$ Houck, J. C., Fed. Proc., 24, 359 (1065).

'Houck, J. G.. Ann. N.Y. Acad. Sci., 105, 765 (1963).

'Leach, A. A., Bise:hem. J., 74, 61 (1960).

${ }^{8}$ Cuthbertson, D. P., in Mammalian Protein Metubolism, edit. by Munro, H. N., and Allison, J, B3., 2, 373 (Academic Press, New York, 1964)

\section{Effect of Dipicolinate on the Heat Denaturation of Proteins}

Dipicolinic acid (DPA, pyridine-2,6-dicarboxylic acid) is synthesized during sporogenesis in spore-forming bacteria and excreted during germination as the calcium salt. Heat resistance of spores has long been thought to be associated with the presence of DPA. Church and Halvorson $^{1}$ reported a quantitative relationship between heat resistance and DPA content in spores. Black et al. ${ }^{2}$ found that at a concentration of DPA greater than $50 \mu \mathrm{g} / \mathrm{mg}$ dry spores the heat susceptibility appears to remain constant and minimal.

This communication describes the results of experiments on the heat treatment of proteins in the presence of the sodium or calcium salts of DPA. Human serum albumin solution becomes turbid when heated at $60^{\circ}$ $95^{\circ} \mathrm{C}$. However, the occurrence of turbidity in 0.05 per cent solution is completely prevented by $10^{-3} \mathrm{M}$ of sodium DPA. A similar effect of relatively small amounts of sodium DPA can also be seen in solutions of bovine serum albumin, ovalbumin and human serum $\gamma$-globulin. The following procedure was used for the precipitation test at the isoelectric point. Two ml. of $3 \times 10^{-1} \mathrm{M}$ sodium DPA was mixed with the samo volume of 1 per cent bovine serum albumin. The mixture was heated at $65^{\circ} \mathrm{C}$. Then $4 \mathrm{ml}$. of $0.2 \mathrm{M}$ acetate buffer, $p \mathrm{H} 4 \cdot 8$, stored at the same temperature, was added and the solution was cooled for $5 \mathrm{~min}$ in water. After centrifugation (3,000 r.p.m., $15 \mathrm{~min}$ ), the supernatant was filtered. Two $\mathrm{ml}$. of the filtrate was mixed with $8 \mathrm{ml}$. of the biuret reagent. The mixture was maintained at $37^{\circ} \mathrm{C}$ for $30 \mathrm{~min}$, and the optical density was measured at $530 \mathrm{~m} \mu$. The results are shown in Fig. 1.

Further experiments were carried out with the sulphydryl group of proteins. One $\mathrm{ml}$. of $3 \times 10^{-1} \mathrm{M}$ sodium DYA was mixed with $1 \mathrm{ml}$. of 1 per cent bovine serum albumin, and then $0.5 \mathrm{ml}$. of $0.5 \mathrm{M}$ phosphate buffer $(p \mathrm{H} 6.8)$ and $0.5 \mathrm{ml}$. of $0.01 \mathrm{M}$ potassium ferricyanide were added. After heating at $90^{\circ} \mathrm{C}$, the solution was cooled for $5 \mathrm{~min}$ in water, and mixed again with $5 \mathrm{ml}$. of the phosphate buffer. The optical density of the filtrate was measured at $420 \mathrm{~m} \mu$. The results are shown in Fig. 2.

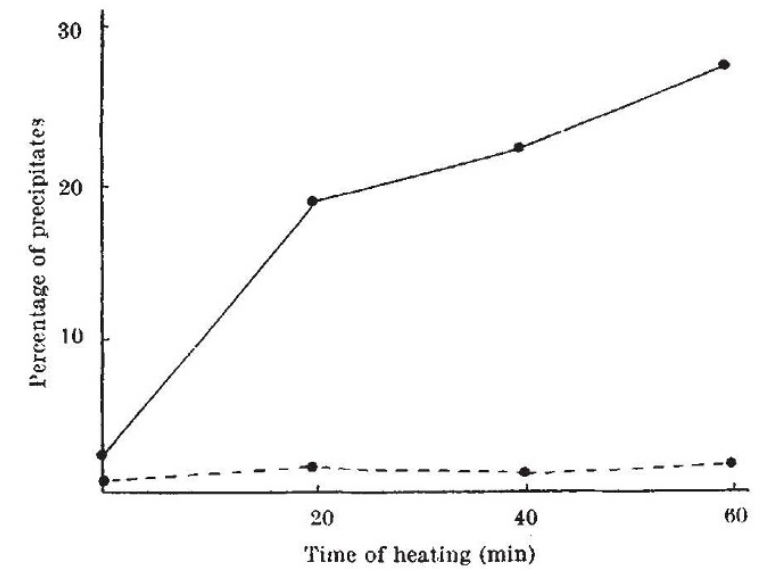

Fig. 1. Precipitation test. The ordinate indicates the percentage of the total amount of protein precipitated. Broken line, material with DPA;

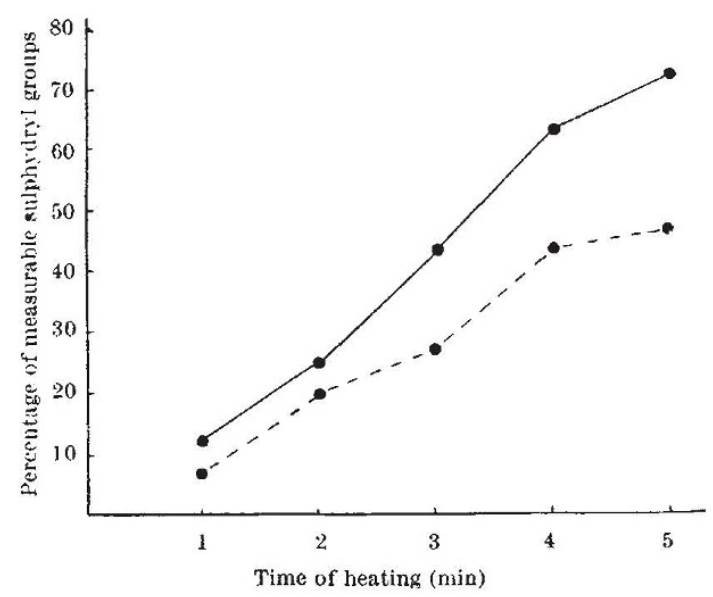

Fig. 2. Appearance of sulphydryl groups. The ordinate indieates the pereentage of the total amount of sulphydryl revealed. Jroken line,
material with DPA; full line, control without DPA.

As shown in Figs. 1 and 2, both the precipitation of protein and the numbers of sulphydryl groups measured are decreased by the addition of sodium DPA. Similar results are obtained when calcium DPA is used. 'These experiments indicate that DPA has a preventive action on the heat denaturation of proteins. This effect seems likely to be connected with the heat resistance of spores.

Y. Mishiro

M. $\mathrm{OCHI}$

Department of Biochemistry,

Nippon Dental College,

Tokyo, Japan.

' Church, B. D., and Halvorson, H., Nature, 183, 124 (1959). 2 Black, S. H., Hashimoto, T., and Gerhardt, P., Canah. J. Miorobiol., 6, 213
(1960).

\section{Inhibition of Protein Synthesis by Cyclo- heximide (Actidione) in Chlorella}

Cycloheximide is an antibiotic produced by Streptomyces griseus. It inhibits the growth of fungi ${ }^{1,2}$, algae ${ }^{3}$, protozoa and higher plants ${ }^{5}$, but has no effect on bacterial growth ${ }^{1}$. In yeast cells ${ }^{6,7}$ and mammalian cells ${ }^{8}$ cycloheximide inhibits both protein and DNA synthesis simultaneously, whereas the inhibition of RNA synthesis is delayed. With intact cells, it was not possible to resolve the controversy over whether the primary effect of cycloheximide was on the synthesis of deoxyribonucleic acid or on the synthesis of protein. Investigations with extracts free of cells $s^{9,10}$, 